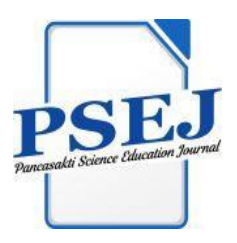

\author{
Pancasakti Science Education Journal \\ PSEJ Volume 4 Nomor 2, Oktober 2019, (Hal. 128 -136) \\ http://scienceeduiournal.org/index.php/PSEJ/issue/view/7 \\ doi: $10.24905 /$ psej. $v 4 i 2.1339$
}

Submitted: 29/07/2019, Accepted: 30/10/2019, Published: 31/10/2019

\title{
Sikap dan Motivasi Siswa Pada Pelajaran Fisika di Sekolah Menengah Atas
}

\author{
Rahmat Perdana $^{1^{*}}$, Cahyono Subiyantoro $^{2}$, Lika Anggraini ${ }^{3}$ \\ ${ }^{1}$ Prodi Pendidikan Fisika, FKIP Universitas Jambi, Indonesia \\ ${ }^{2}$ SMA Ferdy Ferry Putra Kota Jambi, Indonesia \\ ${ }^{3}$ Program Studi Pascasarjana, Pendidikan Matematika dan Ilmu Pendidikan Alam, Universitas Jambi, \\ Indonesia
}

Korespondensi. E-mail: rahmat260997@gmail.com

\begin{abstract}
Abstrak
Sikap sangat penting pada pembelajaran abad 21 sekarang, oleh karena itu, penelitini memeiliki tujuan untuk mengetahui apakah terdapat hubungan antara motivasi dan sikap siswa pada pelajaran fisika di sekolah menengah atas. Penelitian ini menggunakan penelitian kuantitatif dengan rancangan korelasional, sampel yang digunakan pada penelitian ini berjumlah 97 siswa yang diambil menggunakan teknik purposive sampling. Hasil yang didapatkan pada penelitian ini adalah sikap yang dimiliki siswa sekolah menengah atas memiliki kategori baik dan begitu pula motivasi yang dimiliki oleh siswa tersebut, hal ini diperkut dengan hasil korelasi yang telah didapatkan yaitu sebesar 0.697 dan memiliki hubungan yang positif.
\end{abstract}

Kata Kunci: Sikap; Motivasi; Siswa

\section{Attitudes and Motivation of Students in Physics in Senior High School}

\begin{abstract}
The attitude is very important in 21st century learning now, therefore, researchers have the aim to find out whether there are a motivational relationship and the attitude of students in physics in high school. This study uses quantitative research with correlational design, the sample used in this study amounted to 97 students taken using purposive sampling technique. The results obtained in this study are the attitudes possessed by high school students have a good category and so does the motivation possessed by these students, this is related to the results of the correlation that has been obtained which is equal to 0.697 and has a positive relationship.
\end{abstract}

Keywords: Attitudes; Motivation; Students 


\section{PENDAHULUAN}

Pendidikan abad 21 sekarang sangat mengedepankan karakteristik atau perilaku dari seorang siswa. Hal ini sejalan dengan kurikulum yang diterapkan di Indonesia yaitu kurikulum K13 yang menitik beratkan kepada kemampuan afektif siswa. Bukan hanya kognitif dan psikomotorik dari siswa tersebut tetapi afektif juga dijadikan tujuan utama didalam pembelajaran (Sisdiknas, 2013). Khususnya pada pelajaran fisika di jenjang sekolah menengah atas. Dalam tingkat pendidikan sekolah menengah atas, mempelajari berbagai ilmu pengetahuan, salah satu ilmu yang di pelajari tersebut adalah fisika. Fisika merupakan ilmu yang berkembang dari pengamatan gejala alam dan interaksi yang terjadi di dalamnya (Asih, 2017; Arslan, 2015). Selain itu fisika merupakan ilmu sains yang berintegrasi dengan perilaku dan gejala-gelaja fenomena alam yang dikatikan dengan fenomena sekarang atau yang terjadi saat ini (Giancoli, 2014). Prilaku sering kita ibaratkan dengan sikap yang dimiliki oleh siswa tersebut.

Berorientasi pada definisi pendidikan dalam undang-undang, belakangan ini pemerintah Indonesia semakin gencar menerapkan pendidikan berkarakter demi memperbaiki moral generasi masa kini yang semakin memburuk. Pendidikan berkarakter menitik beratkan pada penilaian sikap dan karakter siswanya. Pembentukan karakter dan sikap sangat penting dalam proses pembelajaran (Astalini, Kurniawan, \& Putri, 2018). Dasmo (2010); Ainley, (2011) menyatakan bahwa faktor lain yang mempengaruhi hasil belajar adalah sikap. Sikap merupakan sesuatu yang dipelajari, dan sikap menentukan bagaimana individu bereaksi terhadap situasi serta menentukan apa yang dicari individu dalam kehidupan. Sikap merupakan kemampuan internal yang berperan sekali dalam mengambil tindakan, lebih-lebih bila terbuka berbagai kemungkinan untuk bertindak (Astalini, Kurniawan, \&
Nurfarida, 2018). Hal itu dikarenakan sikap siswa merupakan refleksi dari pikiran siswanya. Jika siswa sudah berpikir bahwa suatu mata pelajaran sangat sulit, maka hal tersebut akan berdampak pada sikapnya selama proses pembelajaran berlangsung.

Menurut Alimen (2008); Hardiyanti, Astalini, \& Kurniawan, (2018), sikap adalah salah satu aspek psikologis penting yang merupakan kecenderungan untuk berperilaku sehingga akan banyak mewarnai perilaku seseorang. Sementara itu, Siswanto (2017) menjelaskan bahwa, sikap seseorang mencakup perasaan seperti suka atau tidak suka yang terkait dengan kecenderungan dalam merespons sesuatu. Sikap juga merupakan ekspresi dari nilai-nilai/pandangan hidup seseorang. Sikap erat berhubungan dengan penanganan dan pengelolaan emosi yang terjadi selama proses pembelajaran, dan berperan penting dalam mengarahkan perilaku manusia. Menurut Boyuk (2011), "Sikap terkait dengan mengatasi dan mengelola emosi yang terjadi selama proses pembelajaran, dan mereka memainkan peran penting dalam mengarahkan perilaku manusia". Sikap memiliki peranan penting dalam menggerakkan perilaku manusia. Dimiyati dan Mudjiono (2013); Maison et al, (2018) juga mengatakan bahwa, Kegiatan atau proses belajar juga dipengaruhi oleh sikap, motivas, konsentrasi, mengolah, menyimpan, menggali dan unjuk berprestasi.

Sikap siswa tentang fisika adalah perasaan terhadap fisika, kesediaan untuk mempelajari, dan kesadaran terhadap manfaat fisika (Dasmo, 2010). Sikap ini sangat menentukan minat dan ketertarikan terhadap mata pelajaran fisika. Semakin besar minatnya terhadap fisika, maka hal tersebut akan mempermudahkannya dalam mempelajari fisika (Kurniawan \& Astalini, 2019). Jika siswa yang kurang berminat terhadap pelajaran, dapat diusahakan agar iamempunyai minat yang lebih besar dengan menjelaskan hal-hal yang menarik dan berguna bagi kehidupan 
serta hal-hal yang berhubungan dengan citacita dalam kaitannya dengan bahan pelajaran yang dipelajari itu (Casuarina, 2017).

Sikap itu berasal dari perasaan seseorang terhadap suatu objek atau sesuatu yang dicerminkan dalam perasaan suka ataupun tidak suka. Siswa yang tidak menyukai fisika dapat dilihat dari hasil belajar dan sikap nya terhadap fisika. Sikap baik negatif maupun positif dalam pembelajaran fisika sangat mepengaruhi hasil belajar di fisika dan sains, yang diketahui bahwa jika siswa bersikap negative terhadap pembelajaran fisika akan membuat pembelajaran sekarang atau kedepannya semakin sulit (Erdmir, 2009). Kurangnya sikap positif siswa terhadap pelajaran fisika menyebabkan berbagai masalah. Siswa yang memiliki sikap negative terhadap fisika akan mengurangi tingkat kepercayaan dirinya dan membuat hasil kinerja buruk yang disebabkan kurangnya mencari informasi untuk menyeleasaikan masalah fisika (Olasimbo, et al 2012). Dan jika siswa memiliki sikap negatif terhadap pelajaran fisika maka mereka juga akan bersikap negative terhadap guru fisika (Guido, 2013).

Menurut Lindsey et al (2012) menyatakan, Maksudnya, dari sikap, kita tidak hanya melihat apakah siswa memiliki ketertarikan secara pribadi dalam fisika, tetapi juga memperhatikan aspek seperti bagaimana pandangan mereka tentang koherensi pengetahuan fisika, relevansi fisika yang mereka pelajari di kelas dengan dunia nyata, dan hubungan antara matematika persamaan dan konsep fisika. Khine (2015); Darmaji et al (2018) Seorang siswa sekolah mungkin telah mempelajari fisika yang melibatkan pengetahuan dan pengalaman belajar fisika, tanpa adanya kepercayaan atau sikap secara gamblang. Namun, dalam mempelajari fisika, siswa mungkin akan memiliki perasaan negatif terhadap aspek spesifik pembelajaran fisika. Dengan demikian, siswa berkeyakinan bahwa eksperimen fisika seringkali tidak berhasil, pelajarannya tidak terkait dengan kehidupan, guru memberi terlalu banyak pekerjaan rumah. Keyakinan ini mungkin mengarah pada sikap terhadap fisika yang negatif. Pada gilirannya, sikap semacam itu dapat menyebabkan penolakan terhadap penelitian lebih lanjut (Astalini et al, 2018; Darmaji, Kurniawan, \& Irdianti, 2019). Dengan demikian, kita dapat melihat sikap sebagai dibangun dari seperangkat keyakinan kecil. Meskipun kepercayaan semacam ini terkadang memiliki semacam konsistensi internal, inkonsistensi mungkin dilakukan. Di bidang pendidikan, fitur yang penting adalah fokus.

Menurut Ibeh et al (2013), Banyak faktor yang dapat mempengaruhi sikap siswa terhadap pembelajaran fisika. Salah satunya adalah motivasi yang dimiliki ole siswa. Alimen (2009); Darmaji et al (2018) juga membahas bahwa, "Pandangan atau sikap seseorang yang baik tentang suatu objek atau situasi tertentu dapat berdampak pada suka atau tidak sukanya". Dapat diajukan sebagai tanggapan terhadap sesuatu yang mewakili atau respons dari suka atau tidaknya terhadap sesuatu. Dengan kata lain, motivasi dari siswa tersebut juga ikut mempengaruhi sikapnya. Dalam pembelajaran, sikap juga merupakan aspek yang patut diperhitungkan. Dalam proses pembelajaran, terutama dalam pelajaran fisika, sikap peserta penting untuk dimiliki (Astalini et al, 2019). Karena proses dari sebuah sikap sangat penting (Kurniawan, Astalini, \& Anggraini, 2018; Astalini et al, 2018). Karena, siswa yang memiliki pandangan ini akan memiliki sikap yang berbeda, dengan siswa yang memiliki pandangan positif selama proses pembelajaran (Astalini et al, 2019; Darmaji et al 2018). Salah satunya adalah motivasi. Menurut Higgins \& Kruglanski, (2000) secara umum, motivasi berarti sesuatu yang mendorong untuk melakukan atau bertindak. Motivasi dapat diartikan sebagai kekuatan (energi) orang yang memiliki tingkat kegigihan dan antusiasme dalam menjalankan aktivitas, baik dari dalam diri individu (motivasi intrinsik) (Higgins \& Kruglanski, 2000). Misalnya, siswa memiliki 
kemauan sendiri untuk belajar fisika, mampu dan berkonsentrasi saat belajar fisika Higgins \& Kruglanski, (2000). Dan dari luar individu (motivasi ekstrinsik), suka mendapat hadiah dan mendapat nilai bagus (Higgins \& Kruglanski, 2000). Siswa yang memiliki sikap negatif terhadap fisika memiliki motivasi kurang untuk keterlibatan kelas, dan juga siswa yang memiliki sikap positif terhadap fisika memiliki motivasi untuk keterlibatan kelas (Guido, 2013). Karena dari itu, penelitian ini bertujuan untuk mengetahui apakah ada kaitan antara sikap dan motivasi pada pelajaran fisika di sekolah menengah atas

\section{METODE}

Desain penelitian yang digunakan dalam penelitian ini adalah metode penelitian Asosiatif Kuantitatif dengan desain penelitian korelasional. Penelitian kuantitatif asosiatif adalah penelitian yang bertujuan untuk mengetahui hubungan antara dua atau lebih variabel (Cohen, Manon \& Morrison, 2007). Karena penelitian ini adalah penelitian asosiatif, maka peneliti mengambil desain penelitian korelasional. Menurut Creswell (2015) "Desain Korelasi adalah prosedur dalam penelitian kuantitatif yang digunakan oleh peneliti untuk mengukur tingkat asosiasi (hubungan) antara dua variabel atau lebih menggunakan prosedur analisis korelasi statistik".

Sampel penelitian ini siswa sekolah menengah atas ferdy ferry putra yang diambil menggunakan teknik purposive sampling dengan jumlah sampel yang diperoleh 97 siswa. Pengambilan sampel Purposive adalah teknik pengambilan sampel berdasarkan kriteria peneliti (Kerlinger, 2014).

Dalam penelitian ini, penelitian ini menggunakan dua angket dan wawancara sebagai instrumen, untuk angket sikap diadopsi dari penelitian Rio Darmawangsa (2018) yang memiliki 54 pernyataan valid dengan nilai Cronbach Alpha 0,9. Dan memiliki 7 indikator, serta angket motivasi diadaptasi dari Elok Sudibyo (2015) memiliki 23 pernyataan valid dengan 12 indikator yang memiliki nilai reliabilitas Cronbach alpha sebesar 0,86, dalam penelitian ini, menggunakan skala Likert 5 (lima) untuk pernyataan positif Sangat Tidak Setuju memiliki skor 1, Tidak setuju memiliki skor 2, Cukup memiliki skor 3, Setuju memiliki skor 4 dan Sangat Setuju 5. Untuk pernyataan negatif Sangat Tidak setuju memiliki skor 5, Tidak setuju memiliki skor 4, Cukup memiliki skor 3, Setuju memiliki skor 2 dan sangat setuju memiliki skor 1)

Data dalam penelitian ini menggunakan data analisis kuantitatif menggunakan program SPSS untuk mencari statistik deskriptif dan inferensial. Statistik deskriptif adalah deskripsi atau penyajian data dalam jumlah besar, dalam hal ini dalam bentuk frekuensi ringkasan, misalnya mode, rata-rata, median, minimum, maksimum dan standar deviasi (Cohen, Manion \& Morrison, 2007). Kesimpulan statistik dari prosedur matematika untuk menggunakan probabilitas dan informasi tentang sampel untuk menarik kesimpulan tentang populasi dari mana sampel mungkin diambil (Gall, 2003). Dalam penelitian ini terdapat uji hipotesis, yaitu hipotesis menggunakan korelasi product moment.

\section{HASIL DAN PEMBAHASAN}

Hasil dari angket sikap yang telah diolah mengenai siswa pada pelajaran Fisika dapat dilihat pada Tabel 1 . 
Pancasakti Science Education Journal, 4 (2), Oktober 2019- (132)

Rahmat Perdana, Cahyono Subiyantoro, Lika Anggraini

Tabel 1. Hasil Sikap siswa terhadap fisika di SMA Ferdy Ferry Putra

\begin{tabular}{|c|c|c|c|c|c|c|c|}
\hline \multicolumn{3}{|c|}{ Category } & \multirow{2}{*}{ Mean } & \multirow{2}{*}{ Mode } & \multirow{2}{*}{ Min } & \multirow{2}{*}{$\operatorname{Max}$} & \multirow{2}{*}{$\%$} \\
\hline Interval & Attitude & Total & & & & & \\
\hline $54.0-97.2$ & Very Not Good & 0 & & & & & 0.0 \\
\hline $97.3-140.4$ & Not Good & 2 & & & & & 2.1 \\
\hline $140.5-186.6$ & Enough & 28 & 190.0 & 195 & 99 & 266 & 28.8 \\
\hline $186.7-226.8$ & Good & 49 & & & & & 50.5 \\
\hline $226.9-270.0$ & Very Good & 18 & & & & & 18.6 \\
\hline TOTAL & & 97 & & & & & 100 \\
\hline
\end{tabular}

Dari abel 1, yang berasal dari 97 responden dari Siswa Ferdy Ferry Putra High School memproses hasil menggunakan aplikasi program SPSS, diperoleh sikap untuk memiliki yang baik sebesar 50,5\% dengan total 49 dari 97 siswa. Kategori cukup $28,8 \%$ untuk total 28 siswa, Sangat baik pada $18,6 \%$ untuk total 18

dari 97 siswa, dan Tidak Baik pada 2,1\% untuk total 2 dari 97 siswa. Dari siswa yang rata-rata 190.0, Mode 195, Nilai Maksimum 266, dan Nilai Minimum 99.

Hasil dari angket motivasi yang telah diolah mengenai siswa pada pelajaran Fisika dapat dilihat pada Tabel 2 .

Tabel 2. Hasil motivasi siswa terhadap fisika di SMA Ferdy Ferry Putra

\begin{tabular}{|c|c|c|c|c|c|c|c|}
\hline \multicolumn{3}{|c|}{ Category } & \multirow{2}{*}{ Mean } & \multirow{2}{*}{ Mode } & \multirow{2}{*}{ Min } & \multirow{2}{*}{ Max } & \multirow{2}{*}{$\%$} \\
\hline Interval & Attitude & Total & & & & & \\
\hline $23.0-41.4$ & Very Not Good & 0 & & & & & 0.0 \\
\hline $41.5-59.8$ & Not Good & 4 & & & & & 4.1 \\
\hline $59.9-78.2$ & Enough & 29 & 82.0 & 85 & 43 & 98 & 29.9 \\
\hline $78.3-96.6$ & Good & 42 & & & & & 43.3 \\
\hline $96.7-115.0$ & Very Good & 22 & & & & & 22.7 \\
\hline TOTAL & & 97 & & & & & 100 \\
\hline
\end{tabular}

Dari Tabel 2, yang berasal dari 97 responden dari Siswa Ferdy ferry putra SMA setelah diolah hasilnya menggunakan aplikasi program SPSS, diperoleh motivasi untuk memiliki yang baik sebesar 43,3\% dengan total 42 dari 97 siswa. Kategori cukup 29,9\% untuk total 29 siswa, Sangat baik pada $22,7 \%$ untuk total 22 dari 97 siswa, dan Tidak Baik pada
4,1\% untuk total 4 dari 97 siswa. Dari 97 siswa Mean 82.0, Mode 85, Nilai Maksimal 98, dan Nilai Minimum 43.

Hasil dari sikap dan motivasi yang telah diolah menggunakan SPSS 21 mengenai siswa pada pelajaran Fisika dapat dilihat pada Tabel 3.

Tabel 3. Hasil hubungan motivasi dan sikap siswa pada pelajaran fisika di SMA Ferdy Ferry Putra

\begin{tabular}{|c|c|c|c|}
\hline & & Motivation & Attitude \\
\hline \multirow{3}{*}{ Motivation } & $\begin{array}{c}\text { Pearson } \\
\text { Correlation }\end{array}$ & 1 & $.697^{\star}$ \\
\hline & Sig. (2-tailed) & & .026 \\
\hline & $\mathrm{N}$ & 97 & 97 \\
\hline \multirow{2}{*}{ Attitude } & $\begin{array}{l}\text { Pearson } \\
\text { Correlation }\end{array}$ & $.697^{*}$ & 1 \\
\hline & Sig. (2-tailed) & $\begin{array}{r}.026 \\
97\end{array}$ & 97 \\
\hline
\end{tabular}

Dari Tabel 3, kita dapat melihat bahwa nilai sig yang didapat sebesar 0.26 kecil dari 0.05 , dapat disimpulkan bahwa ada hubungan antara motivasi dan sikap siswa sekolah menengah atas Ferdy Ferry Putra dengan nilai $\mathrm{R}$ sebesar 0.697 dan positif. Jika nilai sig < 
0.05 maka terdapat hubungan antar kedua variabel tersebut (Gall, 2003).

Hasil analisis data angket pada tabel 1 sikap siswa pada pelajaran fisika di SMA Ferdy Ferry Putra menunjukkan dominan peserta didik berada pada kategori baik. Berdasarkan hasil wawancara, peseta didik yang berkategori baik memiliki sikap yang aktif dalam melakukan, contohnya dalam menemukan hal-hal yang bertentangan dengan hasil eksperimen maka peserta didik menanggapi dengan kritis, memiliki rasa ingin tahu yang tinggi dan pantang menyerah.

"Bagaimana perasaan anda saat melakukan eksperimen?Jelaskan alasannya.

"Saya menyukainya. Melakukan eksperimen/percobaan. Dengan melakukan eksperimen, pelajaran fisika jadi tidak membosankan. Saya juga jadi tau aplikasi hukum-hukum fisika.

"Jika anda kesulitan mencari jawaban atau hal-hal tertentu saat eksperimen, anda lebih suka mencari jawaban sendiri atau bertanya kepada teman?

"Kalo saya masih bisa, saya lebih suka mencari tau sendiri dan baca dibuku. Tapi kalau memang tidak tau, saya baru bertanya ke guru atau teman.

Hasil wawancara yang dilakukan, didapatkan bahwa peserta didik suka melakukan eksperimen, yang menandakan bahwa peserta didik tersebut suka berfikir kritis, menemukan hal-hal baru yang menarik dari fisika lewat penyelidikan yang mereka lakukan. Ilmu Fisika berlandaskan pada konsep-konsep sehingga dalam mempelajari hal-hal abstrak ini akan memiliki hambatan untuk peserta didik dan guru (Civelek, 2014). Dengan melakukan eksperimen, ilmu fisika yang abstrak menjadi lebih mudah dipahami dan diminati peserta didik. Peserta didik yang masih kukuh untuk mencari jawaban atas permasalahan yang sulit dalam penyelidikan menunjukkan kepercayaan diri peserta didik terhadap kemampuannya. Kepercayaan diri peserta didik terhadap kemampuan mereka dalam mempelajari ilmu alam dan matematika sangat menentukan keterlibatan mereka dalam aktivitas penyelidikan (Stefan and Ciomos, 2010; Astalini et al, 2019). Sikap peserta didik yang suka bertanya setelah berusaha mencari solusi atau jawaban tersebut menunjukkan bahwa rasa keingintahuan peserta didik sangat besar terhadap penyelidikan yang dilakukannya. Bentuk Apresiasi dan dukungan untuk penyelidikan ilmiah dari peserta didik menunjukkan bahwa mereka menghargai cara ilmiah mengumpulkan bukti, berpikir kreatif, berpikir rasional, menanggapi secara kritis, dan berkomunikasi, kesimpulan, karena mereka menghadapi situasi kehidupan yang berkaitan dengan sains (Rodger Bybee, 2009; Kurniawan, Astalini, \& Anggraini, 2018).

Berdasarkan tabel 2 dalam kegiatan pembelajaran fisika yang dilakukan di sekolah menengah mengeani motivasi yang paling dominan adalah motivasi yang memiliki kategoris baik sebesar $43.4 \%$. Dari hasil data ini, dapat dikatakan bahwa siswa termotivasi untuk berpartisipasi dalam pembelajaran fisika sudah baik atau rata-rata positif. Temuan di lapangan yang dikategorikan baik diketahui bahwa ketika saat pelajaran fisika saat melakukan eksperimen, siswa dengan senang hati mengimplementasikannya, misalnya, segera bergegas ke laboratorium fisika, duduk di depan pelajaran, dan selalu bertanya dan menjawab pertanyaan ketika berlatih diberikan oleh guru fisika. Selain itu, siswa termotivasi untuk belajar di kelas karena ruang laboratorium yang nyaman yang membuat siswa bersemangat untuk pergi ke laboratorium. Karena ruang kelas yang nyaman dapat menumbuhkan keterampilan siswa dan meningkatkan kesenangan dalam belajar fisika (Rawatee Maharaj-Sharma, 2017).

Kita dapat melihat dati tabel 3. Bahwa nilai sig 0.26 kecil dari 0.05 , dapat disimpulkan bahwa ada hubungan antara motivasi dan sikap siswa di sekolah menengha atas ferdy ferry putra dengan nilai-R sebesar 0.697 dan positif. Jika nilai sig $<0.05$ maka terdapat hubungan antar vaiabel (Gall, 2003). Maksud 


\section{Pancasakti Science Education Journal, 4 (2), Oktober 2019- (134)}

Rahmat Perdana, Cahyono Subiyantoro, Lika Anggraini

dari kategori positif itu sendiri adalah bahwa ada hubungan searah antara variabel $\mathrm{X}$ dan $\mathrm{Y}$, yaitu motivasi dan sikap jika motivasi naik, maka sikap naik, dan jika motivasi turun maka sikapnya juga turun. Maka maksud dari kategori negatif itu sendiri adalah adanya hubungan yang kontradiktif antara variabel $\mathrm{X}$ dan Y, yaitu, jika motivasi meningkat maka belum tentu sikap naik, malah turun, dan jika motivasi turun belum tentu sikap turun, tetapi naik. Ini sesuai dengan Gall, 2003) $r=-1$ adalah korelasi negatif sempurna, artinya ada hubungan kontradiktif antara variabel $\mathrm{X}$ dan $\mathrm{Y}$, jika $\mathrm{X}$ naik/tinggi maka $\mathrm{Y}$ turun/rendah, sedangkan $\mathrm{r}=1$ adalah korelasi sempurna, yang berarti ada hubungan dalam arah variabel $\mathrm{X}$ dan variabel $\mathrm{Y}$, jika $\mathrm{X}$ naik maka $\mathrm{Y}$ naik atau jika $Y$ turun maka $X$ turun.

Menurut Mbajiorgu dan Reid (2006) menyatakan bahwa ada hubungan antara kognitif dan afektif dan bahwa tujuan pendidikan fisika harus merangkul keduanya dan tidak memperlakukan mereka sebagai domain yang saling eksklusif. Implikasinya adalah bahwa sikap dapat dikembangkan dan banyak studi dalam literatur menunjukkan bahwa pendekatan untuk presentasi dan pengorganisasian kurikulum berjalan jauh untuk menentukan pengembangan sikap yang diinginkan pada siswa. Dari pernyataan diatas, serta hasil yang didapatkan pada tabel 3, dapat kita lihat bahwa sikap memiliki hubungan dengan motivasi dalam pelajaran fisika.

\section{SIMPULAN}

Sikap merupakan aspek yang penting didalam kehidupan, khususnya didalam pendidikan, dengan memiliki sikap yang positif, maka akan membuat seseorang akan tersebut lebih baik. Ditambah ketika seorang individu tersebut juga memiliki motivasi belajar yang baik pula yang nantinya dapat mempengaruhi sikap dari seseorang, hal ini dapat dilihat dari hasil penelitian bahwa motivasi dan sikap memiliki hubungan sebesar 0.697 dan memiliki nilai yang positif, yang berarti apabila sikap baik maka motivasi dari sesorang tersebut baik.

Saran dari peneliti yaitu agar para guru dan sekolah untuk meningkatkan sikap serta motvasi yang dimiliki oleh siswa, dikarenakan sikap dan motivasi yang dimiliki siswa dapat membuat hasil belajar lebih maksimal.

\section{DAFTAR PUSTAKA}

Ainley, M. A. (2011). A Cultural Perspective on the Structure of Student Interest in Science. International Journal of Science Education, 51-71.

Alimen, Rolando A. 2008. Attitude toward Physics and Physics Performance, Theories of Learning, and Prospects in Teaching Physics. Liceo Journal of Higher Education Research, Vol. 6 No. 1 :301-320.

Arslan, N. I. (2015). High school students' educational and career interest (sciencetechnology- mathematics) and career adaptabilities. Australian Council for Educational Research, 166-172.

Asih, D, A, P. (2017). Pengaruh Pengguna Fasilitas Belajar di Lingkungan Alam Sekitar Terhadap Keterampilan Proses Sains. Jurnal Formatif, 7(1): 13-21.

Astalini, A., Kurniawan, D. A., \& Sumaryanti. (2018). Sikap Siswa Terhadap Pelajaran Fisika Di Sman Kabupaten Batanghari. Jurnal Ilmu Pendidikan Fisika, 3(2), 59-64

Astalini, A., Kurniawan, D. A., \& Nurfarida, L. Z. (2018). Deskripsi sikap siswa SMA di Batanghari berdasarkan indikator normalitas ilmuwan, adopsi dari sikap ilmiah, ketertarikan memperbanyak waktu, dan ketertarikan berkarir di bidang fisika. Jurnal Riset dan Kajian Pendidikan Fisika. 5(2), 73-80.

Astalini, A., Maison, M., Ikhlas, M., \& Kurniawan, D. A. (2018). The Development Of Students Attitude Instrument Towards Mathematics Physics Class. Edusains, 10(1). 46-52.

Astalini, A., Kurniawan, D. A., \& Putri, A. D. (2018). Identifikasi Sikap Implikasi Sosial dari IPA, Ketertarikan Menambah Waktu Belajar IPA, dan Ketertarikan Berkarir Dibidang IPA Siswa SMP SeKabupaten Muaro Jambi. Jurnal Tarbiyah: Jurnal Ilmiah Kependidikan. 7(2), 93-108. 
Astalini, A., Kurniawan, D. A., Sari, D. K., \& Kurniawan, D. (2019). Description of Scientific Normality, Attitudes of Investigation and Interested Career On Physics in Senior High School. Jurnal Ilmu Pendidikan Fisika, 4(1),

Astalini, A., Darmaji, D., Kurniawan, D, A., \& Destianti, A. (2019). Description of the Dimensions Attitudes towards Science in Junior High School at Muaro Jambi. International Journal of Science: Basic and Applied Research (IJSBAR). 47(1), 1-11.

Boyuk, Hasan Kaya ve Ugur. 2013. Attitude towards Physics Lessons and Physical Experiments Of the High School Students.European Journal of Physics Education Vol.2, No. 1:23-31.

Casuarina, Cut, A. Halim, dan Muhammad Syukri. 2017. Minat, Sikap dan Persepsi Mahasiswa terhadap Pembelajaran Fisika ditijau dari Indeks Prestasi Kumulatif Mahasiswa. Jurnal Ilmiah Mahasiswa (JIM) Pendidikan Fisika, Vol.2, No. 2: 247-252.

Civelek, Turhan, Erdem Ucar \& Hakan Ustunel. 2014.Effects of a Haptic Augmented Simulation on K-12 Students'Achievement and their Attitudes towards Physics, Eurasia Journal of Mathematics, Science \& Technology Education,vol 10(6), Hal. 565574.

Cohen, L., Manion, L., \& Morrison, K. (2007). Research Methods In Education : Routledge.

Cresswel, John W. (2012). Educational Research: Planning, Conducting, And Evaluating Quantitative And Qualitative Research. New York: Pearson

Darmaji, D., Kurniawan, D. A., \& Irdianti. (2019). Physics education students' science process skills. International Journal of Evaluation and Research in Education (IJERE), 8(2), 293-298.

Darmaji, Kurniawan, D. A., Parasdila, H., \& Irdianti. (2018). Description of Science Process Skills' Physics Education Students at Jambi University in Temperature and Heat Materials. The Educational Review, USA, 2(9), 485-498.

Darmaji., Astalini., Maison., Kurniawan, D. A., \& Rahayu, A. (2018). Development Physics Practical Guided Based On
Science Process Skill Using Problem Solving. Edusains. 10(1), 83-96

Darmaji, Kurniawan, D. A., Suryani, A., \& Lestari, A. (2018). An Identification of Physics Pre-Service Teachers' Science Process Skills Through Science Process Skills-Based Practicum Guidebook. Jurnal Ilmiah Pendidikan Fisika Al-Biruni. 7(2), 239-245

Darmawangsa, R., Astalini, A., \& Kurniawan, D. A. (2018). Pengembangan instrument sikap siswa sekolah menengah atas terhadap mata pelajaran fisika. JPF: Jurnal Pendidikan Fisika, 6(1), 107-114.

Dasmo, (2010). Pengaruh Sikap Mahasiswa pada Fisika dan Motivasi Belajar terhadap Hasil Belajar Fisika Dasar Mahasiswa. Jurnal ilmiah factor exacta, vol. 3 no. 2 : $136-144$.

Depdiknas. (2003). Undang-undang RI No.20 tahun 2003. Tentang sistem pendidikan nasional.

Dimiyati, dan Mudjiono. 2013. Belajar dan Pembelajaran. Jakarta: Rineka Cipta.

Erdemir, Naki. 2009. Determining Students' Attitude towards Physics through Problem-Solving Strategy. Asia-Pacific Forum on Science Learning and Teaching, Vol. 10, No. 2: 1-19.

Gall.D.M et al. (2003). Education Research an introduction seventh edition. USA : Pearson Education.Inc

Giancoli, D. C. (2014). Mata Pelajaran Fisika : Prinsip dan Aplikasi Edisi ke 7Jilid 1., Jakarta: Erlangga.

Guido, R. M. (2013). Attitude and Motivation towards Learning Physics. International Journal of Engineering Research \& Technology, 2(11): 2087-2094. https://doi.org/10.1093/nar/gkn1085

Hardiyanti, K., Astalini, A., \& Kurniawan, D. A. (2018). Sikap Siswa Terhadap Mata Pelajaran Fisika Di Sma Negeri 5 Muaro Jambi. Edu Fisika: Jurnal Pendidikan Fisika. 3(2), 1-12.

Higgins, E. T \& Kruglanski, A, W. (2000). Motivational Science Social and Personality Perspectives. USA: Taylor \& Francis.

Ibeh G.F., Onah D.U., Umahi A.E., Ugwuonah F.C., Nnachi N.O., \& Ekpe J.E. 2013. Strategies to Improve Attitude of Secondary School Students towards Physics for Sustainable Technological 
Pancasakti Science Education Journal, 4 (2), Oktober 2019- (136)

Rahmat Perdana, Cahyono Subiyantoro, Lika Anggraini

Developmentin Abakaliki L.G.A, Ebonyi-Nigeria. Journal of Sustainable Development Studie, Vol. 3, No.2: 127135.

Kerlinger, F. N. (2014). Foundations of behavioral research. Yogyakarta: Gadjah Mada University Press.

Khine, Myint Swe. 2015. Attitude Measurements in Science Education: Classic and Contemporary Approaches. USA: Age Publishing Inc.

Kurniawan, D. A., Astalini, A., \& Sari, D. K. (2018). An evaluation analysis of students' attitude towards physics learning at senior high school. Jurnal Penelitian dan Evaluasi Pendidikan. 23(1),

Kurniawan, D, A., Astalini., \& Anggraini,L. (2018). Evaluasi Sikap SMP Terhadap IPA di Kabupaten Muaro Jambi. Jurnal Ilmiah Didaktika: Media Ilmiah Pendidikan dan Pengajaran. 19(1), 124-139.

Lindsey, Beth A., Leonardo Hsu, Homeyra Sadaghiani, Jack W. Taylor, dan Karen Cummings. 2012. Positive Attitudinal Shifts with the Physics by Inquiry Curriculum Across Multiple Implementations. Physics Education Research, Vol. 8, No. 1:1-8.

Maison, M., Astalini, A., Kurniawan, D. A., \& Yuniyarsih, S. (2018). Student's Attitude Description Toward Physics On Secondary School. Edusains, 10(1), 160167

Mbajiorgu, Ngozi dan Norman Reid. 2006. Factors Influencing Curriculum Development in higher Education Physics. England: HEA Physical Science Centre.

Olasimb, O. O., Rotimi C.O. 2012. Attitudes of Students towards the Study of Physics in College of Education Ikere Ekiti, Ekiti State, Nigeria. American International Journal of Contemporary Research, Vol.2, No. 12: 86-89.

Rawatee Maharaj-Sharma, A. S. (2017). Using Ict In Secondary School Science Teaching - What Students And Teachers In Trinidad And Tobago Say. European Journal of Education Studies, 197-211.

Rodger Bybee, B. M. (2009). PISA 2006: An Assessment of Scientific Literacy . JOURNAL OF RESEARCH IN SCIENCE TEACHING, 865-883.
Siswanto. 2017. Penilaian dan Pengukuran Sikap dan Hasil Belajar Peserta Didik. Klaten:Bosscript.

Stefan, M., dan Florestina ciomos. (2010). The $8^{\text {th }}$ and $9^{\text {th }}$ Grades Students' Attitude Towards Teaching and Learning Physics. Acta Didactica Napocensia, 3(3), 7-14. 